DOI: $\underline{\text { https://doi.org/10.15407/techned2019.01.0 } 89}$

\title{
CALIBRATION THERMOELECTRIC HEAT FLUX SENSOR IN THE DIAGNOSTIC SYSTEM OF THERMAL STATE OF ELECTRIC MACHINES
}

Journal

Publisher

ISSN

Issue

Pages
Tekhnichna elektrodynamika

Institute of Electrodynamics National Academy of Science of Ukraine 1607-7970 (print), 2218-1903 (online)

No 1, 2019 (January/February)

$89-92$

\section{Authors}

\section{V.P. Babak*, S.I. Kovtun**}

Institute of Engineering Thermophysics NAS of Ukraine, str. Zheliabova, 2a, Kyiv, 03057,

Ukraine,

e-mail:vdoe@ukr.net; sveta_kovtun@ukr.net

* ORCID ID : http://orcid.org/0000-0002-9066-4307

** ORCID ID : http://orcid.org/0000-0002-6596-3460

\section{Abstract}

Prospects and specific features of the application of thermoelectric heat flow sensors in the systems of diagnostics of the thermal state of electric machines are considered. A method for calibrating sensors is improved by implementing a step-by-step procedure, in resulting the verification procedure without demounting the sensor and can be carried out at the site of operation. The correction factor for the refinement of the conversion factor under operating conditions was determined. The correction is a characteristic of the heat flow sensor and depends on the design, technological and thermophysical parameters of a particular sensor 
instance that was placed to the heat exchange conditions characteristic for the study object. Ref erences 8, figure 1.

Key words: thermoelectric heat flux sensor, conversion factor, monitoring of thermal parameters.

Received: 05.03.2018

Accepted: 01.08 .2018

Published: 10.01 .2019

\section{References}

1. Grishchenko M.A. Analysis of the thermal state of the winding of the armature of the traction electric motor of direct current. Izvestiia Peterburgskogo universiteta putei soobshcheniia. 2009. No 3. Pp. 73-78. (Rus)

2. Gromov G.G. Method for calibrating thermoelectric heat flow sensors. Patent 2577389 RU. 2016. (Rus)

3. Artemchuk V.O., Bilan T.R., Blinov I.V. Theoretical and applied bases of economic, ecological and technological functioning of energy objects. Kyiv: Department of Physical and Technical Problems of Power Engineering NAS of Ukraine, 2017. 312 p. (Ukr)

4. Grischenko T.G., Dekusha L.V., Vorobev L.I. Heatmetry: theory, metrology, practice. Book.1: Me-thods and means of heat flow measuring. Kyiv: Institute of Engineering Thermophysics NAS of Ukraine, 2017. 312 p. (Rus)

5. Howey D.A., Childs P.R.N., Holmes A.S. Air-gap convection in rotating electrical machines. I EEE Transactions on Industrial Electronics

. 2012. Vol. 59. No 3. Pp. 1367-1375. DOI:

https://doi.org/10.1109/TIE.2010.2100337

6. Jussila H.K., Mityakov A.V., Sapozhnikov S.Z., Mityakov V.Y., Pyrhönen J. Local Heat Flux 
Measurement in a Permanent Magnet Motor at No Load. IEEE Transactions on Industrial Electronics . 2013. Vol. 60. Issue 11.

Pp. $4852-4860$.

DOI: htt

ps://doi.org/10.1109/TIE.2012.2222853

7. Lartz D.J., Cudney H.H., Diller T.E. Heat flux measurement used for feedforward temperature control. Proc. 10 Ith Inter. Heat Transfer Conference. Brighton. UK, 1994. Vol. 2.

Pp. 261-266.

8. Pontt J. Diagnostics of Insulation Condition and Risk Evaluation of Electrical Machines Employed in Mining Application. IEEE Conferences Industry Applications Society Annual Meeting

(IAS). 2009. Houston, TX, USA. Pp. 1-3. DOI: https:// doi.org/10.1109//AS.2009.5324808

$\underline{\text { PDF }}$ 